УДК 327:316.74

https://doi.org/10.34142/24130060.2020.20.1.11

\title{
КІНОФЕСТИВАЛЬ ЯК ІНСТРУМЕНТ «М'ЯКОЇ СИЛИ» КУЛЬТУРНОЇ ДИПЛОМАТІї У МІЖНАРОДНИХ ВІДНОСИНАХ
}

\author{
P. О. Комар \\ Національний аерокосмічний університет ім. М. Е. Жуковського «XАI»
}

\section{С. М. Солових}

Харківський національний університет імені В. Н. Каразіна

У статті визначається, щуо кінематограф, окрім мистещьького навантаження, на сьогодні є важливою складовою культурної дипломатії. Обтрунтовано, щзо культурна дипломатія, як інструмент міжнародної політики «м'якої сили», відіграє у міжнародних відносинах визначальну роль. Проаналізовано основні кінофестивалі України. Визначено роль держави в їх організачії. Визначено взаємозв'язок ичих кінофестивалей та формуванням позитивного іміджу України на міжнародній арені.

Ключові слова: публічна дипломатія, політика м'якої сили, імідж держави, міжнародна політика, кіномистецтвво, кінофестиваль.

\section{КИНОФЕСТИВАЛЬ КАК ИНСТРУМЕНТ «МЯГКОЙ СИЛЫ» КУЛЬТУРНОЙ ДИПЛОМАТИИ В МЕЖДУНАРОДНЫХ ОТНОШЕНИЯХ}

\author{
Р. А. Комар, Е. Н. Соловых
}

В статье определяется, что кинематограф, кроме художественного нагрузки, сегодня является важной составляющей культурной дипломатии. Обосновано, что культурная дипломатия как инструмент международной политики «мягкой сильл», играет в международных отношениях определяюшую роль. Проанализировань основные кинофестивале Украины. Определена роль государства в их организачии. Определена взаимосвязь этих кинофестивалей с формированием позитивного имиджа Украины на международной арене.

Ключевые слова: публичная дипломатия, политика мягкой силь, имидж государства, международная политика, киноискусство, кинофестиваль.

\section{THE FILM FESTIVAL AS AN INSTRUMENT OF «SOFT POWER» OF CULTURAL DIPLOMACY IN INTERNATIONAL RELATIONS}

\section{R. Komar, E. Solovykh}

The article defines that cinema, in addition to artistic load, is today an important component of cultural diplomacy. The role and place of cultural diplomacy among other types of diplomacy are revealed. It is also argued that cultural diplomacy, as an instrument of international soft power policy, has played a decisive role in international relations, which since the 1990s has been the basis of most of the world's leading countries. It is stated that modern 
cinema is not only informing people about certain events, but also creating the history of one's own country with the help of "soft power". It has been proven that the use of film festivals mobilizes public opinion of both internal and external audiences and strengthens the level of trust in the actions of governments, allows a fuller understanding of foreign audiences. The main film festivals of Ukraine, which took place in different regions of Ukraine as of 2020, are analyzed, specific features of each of them are identified, in particular, the city where the film festival takes place and the year of its foundation, as well as those countries that participated. The role of the state in the organization of film festivals has been revealed. The interrelation of these film festivals with the formation of a positive image of Ukraine in the international arena is analyzed. As a result of the study, it was concluded that Ukraine is actively involved in film festivals in its country, which indicates its openness and at the same time, the presentation in the international arena. It should be noted that although the topics of film festivals are quite diverse, and the number of participants in these events is increasing every year, but the state policy in the field of culture is not very effective, in particular, in the organizational policy of film festivals. sites that cover various film festivals, however, it is often outdated and out of date, or nonexistent. In addition, the article provides an overview of the participating countries that have participated in various Ukrainian film festivals during their holding, and found that their number ranges from eight to 4,000, however, it should be noted that they were mostly represented by countries with CIS and European countries. Thus, the participation of one or another country of the world in film festivals held in Ukraine is a reflection of the policy pursued within each of the states.

Key words: public diplomacy, soft power policy, state image, international politics, film art, film festival.

Постановка проблеми. Для успішного просування та реалізації національних інтересів будь-якої держави одним із найважливіших завдань зовнішньої політики є створення позитивного іміджу. Починаючи 3 90-х років минулого століття, більшість провідних країн світу за основу своєї зовнішньої політики взяли концепцію «м'якої сили». Засадничими для цієї концепції стали економіка, людський капітал, інформація, освіта, культура, а основним інструментом іiі реалізації стала дипломатія (публічна, культурна, гуманітарна тощо). Серед цього ряду особливе місце посідає культурна дипломатія. Пропагування культури, традицій та історичних особливостей країни через різноманітні заходи, стає основним знаряддям формування позитивного іміджу держави на міжнародній арені. Одним із важливих сучасних складових культурної дипломатії $є$ кінематограф. Саме через кіномистецтво у сучасному інформаційному суспільстві відбувається не тільки обмін культурними особливостями між державами, але здійснюється формування певних паттернів поведінки людини. Тому, обраний напрямок дослідження є актуальним. 
Аналіз актуальних досліджень. Культурна дипломатія останнім часом стає предметом багатьох наукових розвідок. У працях закордонних вчених Дж. Віларда, М. Камінгса, М. Кілбейна, Є. Онуха, Дж. Ная, Ф. Тейлора досліджуються питання культурної дипломатії та іiі впливу на зміст та напрямки міжнародної політики. В українській науковій практиці питанням культурної дипломатії та іï впливу на міжнародні відносини присвячені роботи С. Гуцал, Н. Мусієнко, О. Кучмій, І. Сухорольської, Н. Сербіної, Я. Турчин та ін. Проте, впливу кінематографу на міжнародну політику, як інструменту культурної дипломатії, присвячено не достатньо досліджень.

Мета статті - проаналізувати вплив кінематографа, як складової культурної дипломатії, на формування позитивного іміджу держави на міжнародній арені.

Виклад основного матеріалу. У сучасних умовах змінюється ставлення щодо самих політичних інструментів, а саме - способів репрезентації країн на світовій арені. Саме таким інструментом культурного представлення держави є кінематограф, який як у середині самої держави, так і за іiі межами, щороку набуває все більшої цінності як засіб політики «М’якої сили».

Кіно стає невід'ємною частиною життя практично кожної людини. Популярні фільми дивляться широкі верстви населення найрізноманітних поколінь i соціальних статусів. Грамотне використання засобів кінематографу як інструменту «м’якої сили» може суттєво впливати на свідомість людини, формуючи у неї певне ставлення до політичних подій, визначаючи певний тип політичної поведінки, та, взагалі, нав’язувати певні стереотипи та ціннісні орієнтири.

Кінематограф стає предметом досліджень різних наукових сфер. Серед грунтовних досліджень є праці С. Кара-Мурзи «Маніпуляція свідомістю» (2003), Г. Шиллера зі схожою назвою - «Маніпулятори свідомістю» (1980). Саме тому держава повинна багато уваги приділяти формуванню образів 
національних кіногероїв, які, так чи інакше, ототожнюються 3 політичною системою цієї країни.

Ще однією соціально-психологічною особливістю кінематографу, що відрізняє його від інших інформаційних джерел, $є$ те, що кіно не може інформувати людину щоденно про політичні події. Таким чином, кінематограф завжди знаходиться над політичними подіями як би «зверху», та відображає базові ідеологічні установи i отримує моральне право створювати історію своєї країни.

Однією з перших книг щодо вітчизняного кінематографа, була книга Я. Савченка «Народження українського радянського кіно» (1930). На початку 60-х років американський кінознавець Б. Берест видав свою полемічну працю «Історія українського кіно» (1962) та висвітлив точку зору щодо радянських істориків.

Пошуки кінознавчої науки на сторінках наукових видань, монографічних видань, які були присвячені лише окремим проблемам вітчизняного кіно та довгий час приховувались, почали активно здійснюватися сучасними дослідниками. Зокрема, такі нові імпульси щодо проблем українського кіно можна було простежити у роботах I. Корнієнка «Півстоліття українського радянського кіно» (1970), «Кино советской Украины» (1975). Радянське кіно стає об’єктом дослідження науковців. Автори у деяких текстах зосереджуються на історико-соціальному контексті та звертають увагу на ті загальноцивілізаційні конфлікти, які стосуються художньої української культури та мають безпосередній вплив на економічні, політичні і соціокультурні сфери.

Особливо цінним у наукових дослідженнях нам видається широке використання архівних матеріалів. Це, насамперед, стосується історичної розвідки харківського дослідника В. Миславського, присвяченої першому десятиліттю ігрового кіно, з його кадрами 3 дореволюційних фільмів.

Ті виклики, які поставило нам сучасне інформаційне суспільство, сприяють нівелюванню кордонів між зовнішньої та внутрішньою політикою 
держав. Значну роль у цьому відіграє саме культурна дипломатія, як важлива складова зовнішньої політики будь-якої держави світу. Всесвітньо відомому Генрі Кіссинджеру належать такі слова: «Будь-яка дипломатія є продовження війни іншими засобами» (Kissyndzher, 2018). На сьогодні провідне місце серед різних видів дипломатії, яких досить чимало (цифрова, військова, човникова, економічна, гуманітарна тощо) належить саме культурній дипломатії. Адже у час, коли між державами виникають різноманітні конфлікти та набувають поширення різні форми інформаційних війн, роль культури як елемента «м’якої сили» неможливо переоцінити.

Використання кінофестивалів мобілізує громадську думку як внутрішньої, так і зовнішньої аудиторії, та зміцнює рівень довіри до дій урядів, дає змогу повніше осмислити закордонну аудиторію. Фестиваль фільмів часто залишається єдиним майданчиком, з якого є шанс стартувати у світ кіно та має широкий перелік переваг та нових можливостей. Звичайно, можна викласти фільм в Інтернеті, якщо він захопливий та цікавий, його подивиться багато людей. Вони навіть поставлять лайки та напишуть свої позитивні коментарі. Але сприйняття фільму в темній залі кінотеатру на великому екрані і біля екрану монітору чи ноутбуку буде абсолютно різне. Можна 3 впевненістю стверджувати, що фільм, який ми побачимо на кінофестивалі в конкурсній програмі, запам'ятається глядачам набагато краще, ніж ситуативний перегляд вдома.

Фестивальна аудиторія має можливість відвідати кінофестиваль та представити своє кіно аудиторії. Так як фестивалі проводяться майже у всіх куточках світу - то це можна ще розглядати як шанс «надихатися» новими країнами, краще пізнати їх культуру, особливості менталітету. Любов глядачів до фільму - це можливість знайти дистриб'юторів і підписати вигідний контракт на комерційну дистрибуцію та створити сумісно наступний кінематографічний шедевр.

Піар фільму створює позитивний імідж у своїй країні та на міжнародній арені. Преса полює за цікавими новинами, а фільм у конкурсі 
відомого фестивалю - це, безперечно, визначна подія. У ЗМІ будуть писати про кіно, активно обговорювати; героїв фільмів будуть запрошувати на ТВшоу, фотосесії та інтерв’ю.

У цьому випадку будь-якій країні вже буде легше залучити вже відомих «потрібних» людей, адже успіх - завжди «примагнічує» до роботи найкращих. Якщо говорити про популяризацію українського кіно загалом, то чим частіше на міжнародній арені серед переможців кінофестивалів (або хоча б його учасників) буде звучати саме назва нашої країни - «Україна» у позитивному аспекті, тим більше буде зростати іï авторитет і значення у світі.

Так, у 2019 році Україна була представлена Національним павільйоном на кіноринку у конкурсних програмах 72 Міжнародного Канського кінофестивалю. Український павільйон був своєрідним закликом до закордонних кінематографістів та продемонстрував горизонт можливостей для роботи над фільмами в Україні.

Під час роботи Українського павільйону була представлена вичерпна інформація про стан самої індустрії, аналітичні та статистичні матеріали про обсяг ринку, законодавство у сфері кінематографа. Було підготовлено «Каталог українських фільмів», до якого увійшли ігрові художні фільми: короткометражні фільми, повнометражні фільми, завершені виробництвом; повнометражні фільми, що перебувають на стадії виробництва, а також каталог українських кіно-продюсерів. Були заплановані зустрічі 3 українськими продюсерами, дистрибуторами, представниками Держкіно та представниками українських кінофестивалів.

Окрім павільйону на кіноринку, Україна на фестивалі була представлена такими подіями: прийом за підтримки Посольства України у Франції та бізнес-ланч, у рамках якого міжнародній спільноті було представлено шість проектів нових українських фільмів на етапі їх виробництва. 
Скільки в Україні проходить кінофестивалів? Щоб відповісти на це запитання, ми проаналізували сайт Міністерства культури України, проте, такої інформації не знайшли, тому ми розглянули зміст двох сайтів «Кінофестивалі - Кіно в Україні» та «Каталог кінофестивалів з усього світу». Аналіз змісту цих сайтів свідчить, що в Україні на сьогодні заявлено 21 фестиваль. Варто зазначити, що на останньому сайті (Кінофестивалі - Кіно в Україні) загальна кількість кінофестивалів нараховує більш ніж 1500, що представляють різні держави світу. Що стосується кінофестивалів України, то 3 21-го статус міжнародного мають 19. Згідно нашого дослідження, загальна кількість фестивалів, які діяли та діють в Україні, складає 28, аналіз яких надано у таблиці.

Кінофестивалі України (станом на 2020 рік)

\begin{tabular}{|c|c|c|c|c|}
\hline $\begin{array}{l}\text { № } \\
3 / \Pi\end{array}$ & $\begin{array}{l}\text { Назва. Місто. } \\
\text { Тривалість }\end{array}$ & \multicolumn{2}{|c|}{ Країни-учасники } & Висновки \\
\hline 1 & 2 & \multicolumn{2}{|c|}{3} & 4 \\
\hline \multirow[t]{2}{*}{1.} & \multirow[t]{2}{*}{$\begin{array}{l}\text { Київський } \\
\text { міжнародний } \\
\text { фестиваль } \\
\text { короткометражних } \\
\text { фільмів, або KISFF. }\end{array}$} & \multicolumn{2}{|c|}{$\begin{array}{l}\text { «Від Зімбабве до Ісландії, } \\
\text { від Тайваню до Чілі»- усі } \\
\text { континенти представлені у } \\
\text { нашій програмі». } \\
\text { Було показано } 76 \text { фільмів } \\
338 \text { країн світу: Франція, } \\
\text { Нідерланди, Україна, } \\
\text { Польща, Грузія; а також } \\
\text { були різні спільні проекти, } \\
\text { наприклад, України } \\
\text { Латвією тощо. }\end{array}$} & 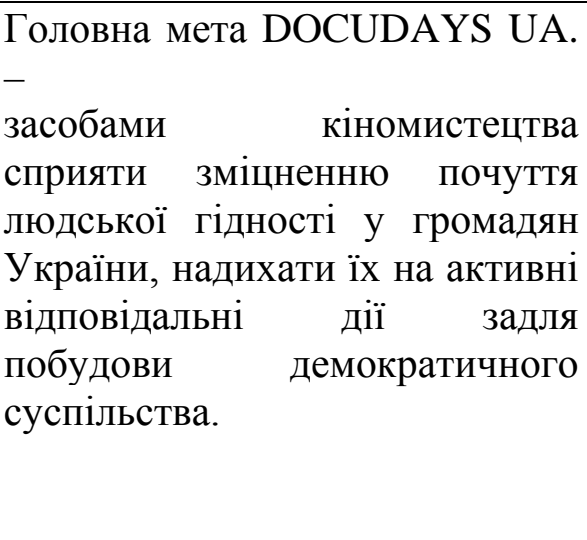 \\
\hline & & м. Київ. & $\begin{array}{l}2002 \text { р.; } \\
8 \text { років }\end{array}$ & \\
\hline 2. & $\begin{array}{l}\text { Київський } \\
\text { міжнародний } \\
\text { кінофестиваль } \\
\text { «Молодість» }\end{array}$ & м. Київ & $\begin{array}{l}1970 \text { р.; } \\
49 \text { років }\end{array}$ & 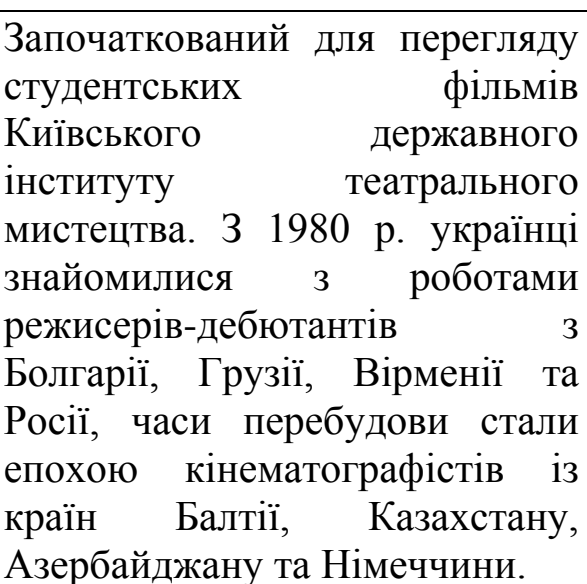 \\
\hline 3. & $\begin{array}{l}\text { «Wiz-Art» } \\
\text { Міжнародний }\end{array}$ & м. Львів & $\begin{array}{l}2008 \text { р; } \\
12 \text { років }\end{array}$ & $\begin{array}{llr}\text { Перегляд } \\
\text { кінотеатрах }\end{array} \quad$ y $\begin{array}{r}\text { Львівських } \\
\text { найцікавіших }\end{array}$ \\
\hline
\end{tabular}




\begin{tabular}{|c|c|c|c|c|}
\hline & $\begin{array}{l}\text { фестиваль } \\
\text { короткометражних } \\
\text { фільмів }\end{array}$ & & & $\begin{array}{l}\text { короткометражних фільмів } 3 \\
\text { країн Скандинавії, Нідерландів, } \\
\text { Іспанії, Франції, країн Азї, } \\
\text { Великої } \text { Британії, США, } \\
\text { Німеччини та інших країн. }\end{array}$ \\
\hline 4. & $\begin{array}{l}\text { «Дитятко» } \\
\text { Міжнародний } \\
\text { дитячий телевізійний } \\
\text { фестиваль }\end{array}$ & м. Харків & $\begin{array}{l}2009 \text { р.; } \\
11 \text { років }\end{array}$ & $\begin{array}{l}\text { Участь беруть студійці з усіх } \\
\text { регіонів України. Оцінює ї } \\
\text { роботи Міжнародне журі } 3 \\
\text { представників із Фінляндії, } \\
\text { Німеччини, Білорусі, Сербії, } \\
\text { Латвії та України. } \\
\text { У } 2019 \text { р. оргкомітет отримав } \\
1500 \text { робіт з } 98 \text { країн світу. }\end{array}$ \\
\hline 5. & $\begin{array}{l}\text { Міжнародний } \\
\text { кінофестиваль } \\
\text { "БРУКІВКА" }\end{array}$ & $\begin{array}{c}\text { м. } \\
\text { Кам'янець- } \\
\text { Подільський }\end{array}$ & $\begin{array}{c}2017 \text { р.; } \\
3 \text { роки }\end{array}$ & $\begin{array}{l}3 \text { 2018-2019 рік на фестиваль } \\
\text { було надіслано понад } 4000 \\
\text { робіт з } 122 \text { країн світу. } \\
\text { Серед журі - відомі } \\
\text { кінокритики, режисери та } \\
\text { продюсери з України та США. }\end{array}$ \\
\hline 6. & $\begin{array}{l}\text { «Best Sci Fi» } \\
\text { Міжнародний } \\
\text { фестиваль-кінооляд } \\
\text { фільмів в жанрах } \\
\text { «фантастика» } \\
\text { «фэнтезі» }\end{array}$ & $\begin{array}{l}\text { Київ, Львів, } \\
\text { Одеса, } \\
\text { Харків, } \\
\text { Дніпро, } \\
\text { та інші міста } \\
\text { України }\end{array}$ & $\begin{array}{c}2017 \text { р.; } \\
4 \text { роки }\end{array}$ & $\begin{array}{l}\text { США, Великобританія, Ізраїль, } \\
\text { Сербія, Італія, Індія, Франція, } \\
\text { Польща, Латвія, Білорусь, } \\
\text { Вірменія, Казахстан, Росія, } \\
\text { ПАР, Ефіопія, Канада, Мексика } \\
\text { та ін.; } \\
\text { Члени відбіркової комісії - } 3 \\
\text { України, США, Великобританії. }\end{array}$ \\
\hline 7. & $\begin{array}{l}\text { Київський } \\
\text { міжнародний } \\
\text { фестиваль реклами }\end{array}$ & $\begin{array}{l}\text { м. Київ; } \\
\text { м. Одеса }\end{array}$ & $\begin{array}{l}2000 \text { р.; } \\
20 \text { років }\end{array}$ & $\begin{array}{l}\text { Лише у } 2018 \text { р. } 85 \text { членів-журі } \\
\text { iз } 27 \text { країн світу оцінили } 655 \\
\text { конкурсних робіт } 120 \text { агентств } \\
\text { - учасників з } 10 \text { країн світу. }\end{array}$ \\
\hline 8. & $\begin{array}{l}\text { «New Vision» } \\
\text { Міжнародний } \\
\text { фестиваль } \\
\text { короткометражного } \\
\text { кіно }\end{array}$ & м. Київ & $\begin{array}{l}2009 \text { р.; } \\
9 \text { років }\end{array}$ & $\begin{array}{l}\text { Брали участь такі країни, як } \\
\text { Польща, Німеччина; Австрія; } \\
\text { Іспанія; спільні роботи } \\
\text { представляли Бельгія та } \\
\text { Франція. }\end{array}$ \\
\hline 9. & $\begin{array}{l}\text { Одеський } \\
\text { міжнародний } \\
\text { кінофестиваль }\end{array}$ & м. Одеса & $\begin{array}{l}2009 \text { р.; } \\
10 \text { років }\end{array}$ & $\begin{array}{l}\text { Журі - представники з різних } \\
\text { країн, зокрема, Бельгії, США, } \\
\text { Чехії, Ірландії, Грузії, Польщі, } \\
\text { Ірану, України, Польщі, Італії, } \\
\text { Франції, Швеції. }\end{array}$ \\
\hline 10. & $\begin{array}{l}\text { «КиТЫ» } \\
\text { Молодіжний } \quad \text { кіно- } \\
\text { проект }\end{array}$ & м. Маріуполь & $\begin{array}{l}2011 \text { р.; } \\
9 \text { років }\end{array}$ & $\begin{array}{l}\text { Лише у } 2017 \text { р. на фестивалі } \\
\text { прийшло } 420 \text { заявок } 3 \text { країн } \\
\text { світу, зокрема, } 3 \text { України, } \\
\text { Білорусі, } \\
\text { Киргизстану, Естонї̈, Бельгї, } \\
\text { Греції, Ірану. }\end{array}$ \\
\hline 11. & $\begin{array}{l}\text { «Kids Movie Fest» } \\
\text { Міжнародний } \\
\text { фестиваль фільмів, } \\
\text { створений дітьми }\end{array}$ & м. Київ & 3 роки & $\begin{array}{l}\text { Лише у } 2109 \text { р. } \\
\text { близько } 200 \text { робіт } 3 \text { понад } 60 \\
\text { країн світу, зокрема } 49 \text { фільмів } \\
\text { зі США. }\end{array}$ \\
\hline
\end{tabular}




\begin{tabular}{|c|c|c|c|c|}
\hline 12. & $\begin{array}{l}\text { Міжнародний } \\
\text { фестиваль актуальної } \\
\text { анімації та медіа- } \\
\text { мистецтва } \\
\text { «INOLEUM» }\end{array}$ & & $\begin{array}{l}\text { Заснований } \\
\text { у } 2006 \text { р. у } \\
\text { м. Москва; } \\
\text { у } 2014 \text { р. } \\
\text { переїхав до } \\
\text { м. Києва }\end{array}$ & $\begin{array}{l}\text { Учасники з } 250 \text { країн світу, } \\
\text { зокрема, Франції, Японії, } \\
\text { Великобританії, } \\
\text { Аргентини, Бельгії та ін. }\end{array}$ \\
\hline 13. & $\begin{array}{l}\text { «Кінокимерія» } \\
\text { фестиваль } \\
\text { непрофесійного кіно }\end{array}$ & м. Херсон & $\begin{array}{l}2006 \text { р.; } \\
14 \text { років }\end{array}$ & $\begin{array}{l}\text { Лише у } 2019 \text { p. серед } \\
\text { переможців та номінантів були } \\
\text { представники } 3 \text { Росії, Данії, } \\
\text { Казахстану, Іспанії, Вірменії, } \\
\text { Болгарії. }\end{array}$ \\
\hline 14. & $\begin{array}{l}\text { Міжнародний } \\
\text { фестиваль } \\
\text { православного кіно } \\
\text { «Покров» }\end{array}$ & м. Київ & $\begin{array}{l}2003 \text { р.; } \\
17 \text { років }\end{array}$ & $\begin{array}{l}\text { До 10-річчя фестивалю було } \\
\text { показано більш ніж сорок } \\
\text { конкурсних робіт кращих } \\
\text { режисерів України, Росії і } \\
\text { Білорусі. } \\
\text { Лише у } 2019 \text { р. участь беруть } \\
68 \text { фільмів з України, Білорусі, } \\
\text { Грузії, Македонії, Вірменії, } \\
\text { Азербайджана, Литви, Канади, } \\
\text { Польщі, Сербії та Росії. }\end{array}$ \\
\hline 15. & $\begin{array}{l}\text { «Громадський } \\
\text { проектор» } \\
\text { Український } \\
\text { фестиваль } \\
\text { короткометражного } \\
\text { кіно }\end{array}$ & м. Миколаїв & $\begin{array}{l}2013 \text { р.; } \\
6 \text { років }\end{array}$ & Росія, Білорусь, США та інші. \\
\hline 16. & $\begin{array}{l}\text { «MOLODIYA» } \\
\text { Фестиваль соціальної } \\
\text { відео-реклами }\end{array}$ & м. Київ & $\begin{array}{l}2010 \mathrm{p} . \\
9 \text { років }\end{array}$ & $\begin{array}{l}\text { Участь беруть лише українські } \\
\text { кінематографісти. }\end{array}$ \\
\hline 17. & «Корона Карпат» & $\begin{array}{c}\text { м. } \\
\text { Трускавець }\end{array}$ & $\begin{array}{l}32009 \text { р.; } \\
10 \text { років }\end{array}$ & $\begin{array}{l}\text { Фільми спільного виробництва } \\
\text { Україна, Польща, Македонія; } \\
\text { Україна, Франція, Ісландія; а } \\
\text { також Литви, Білорусі, Росії, } \\
\text { Болгарії, Сербії, Румунії, США, } \\
\text { Швеції. }\end{array}$ \\
\hline 18. & $\begin{array}{l}\text { «Food Film Fest» } \\
\text { Фестиваль } \\
\text { короткометражних } \\
\text { фільмів про їжу }\end{array}$ & м. Київ & $\begin{array}{l}2014 \text { p., } \\
5 \text { років }\end{array}$ & $\begin{array}{l}\text { Покази фестивалю відбувались } \\
\text { у таких країнах як: Казахстан } \\
\text { (Алмати), Білорусь (Мінськ), } \\
\text { Туреччина } \\
\text { Німеччина (Берлін). }\end{array}$ \\
\hline 19. & $\begin{array}{l}\text { Кінофестиваль } \\
\text { «Відкрита Ніч» }\end{array}$ & $\begin{array}{l}\text { м. Київ, } \\
\text { Андріївський } \\
\text { узвіз }\end{array}$ & $\begin{array}{l}1997 \text { р.; } \\
22 \text { роки }\end{array}$ & $\begin{array}{l}\text { В он-лайн трансляціях, крім } 30 \\
\text { українських міст, беруть участь } \\
\text { країни Свропи та Канади. У } \\
\text { складі журі були відомі митці } 3 \\
\text { Польщі та США. }\end{array}$ \\
\hline 20. & $\begin{array}{l}\text { «Міжнародний } \\
\text { ВінниціЯнський» } \\
\text { фестиваль } \\
\text { комедійного } \\
\text { пародійного кіно }\end{array}$ & м. Вінниця & $\begin{array}{l}32006 \text { р.; } \\
13 \text { років }\end{array}$ & $\begin{array}{l}\text { Брали участь представники } 3 \\
45 \text { країн світу, до складу журі } \\
\text { входять фахівці у сфері кіно зі } \\
\text { США, Німеччини, Ізраїлю, } \\
\text { Росії, Білорусі тощо. }\end{array}$ \\
\hline
\end{tabular}




\begin{tabular}{|c|c|c|c|c|}
\hline 21. & $\begin{array}{l}\text { «Ірпінський } \\
\text { кінофестиваль» - } \\
\text { міжнародний } \\
\text { некомерційний } \\
\text { фестиваль } \\
\text { альтернативного } \\
\text { (паралельного) } \\
\text { кінематографу» }\end{array}$ & м. Ірпінь & $\begin{array}{l}32003 \text { р.; } \\
16 \text { років }\end{array}$ & 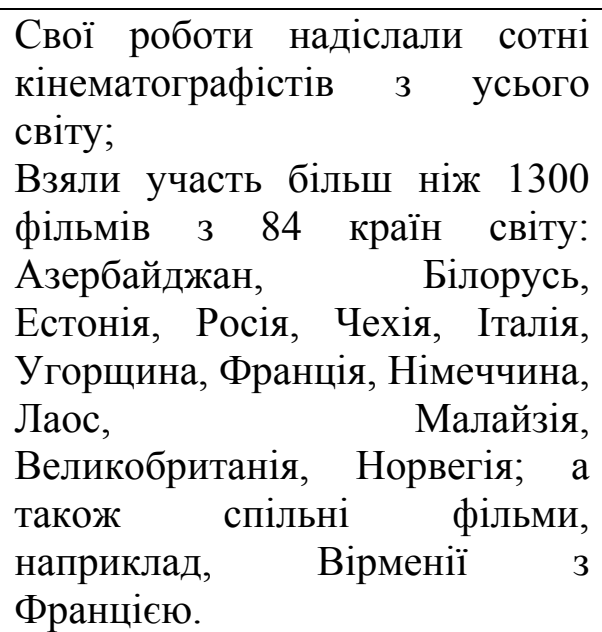 \\
\hline 22. & $\begin{array}{l}\text { «Міжнародний } \\
\text { фестиваль кіно та } \\
\text { урбаністики 86» }\end{array}$ & м. Славутич & $\begin{array}{c}32014 \mathrm{p} . \\
5 \mathrm{p} .\end{array}$ & $\begin{array}{l}\text { У конкурсі брали участь } 12 \\
\text { фільмів - } 5 \text { українських і } 7 \\
\text { зарубіжних, } \\
\text { авторами } 3 \text { країн, які брали } \\
\text { участь у будівництві Славутича } \\
\text { (Литва, Латвія, СРСР, Естонія, } \\
\text { Грузія, Азербайджан, Вірменія, } \\
\text { Україна та Росія.) }\end{array}$ \\
\hline 23. & $\begin{array}{l}\text { Перший Північний } \\
\text { український } \\
\text { кінофестиваль } \\
\text { Фестиваль } \\
\text { некомерційною } \\
\text { ініціативою } \\
\text { Українського } \\
\text { інституту в Швеції у } \\
\text { співпраці } 3 \text { Ukraine } \\
\text { Research Group та за } \\
\text { інформаційної } \\
\text { підтримки } \\
\text { Посольства України у } \\
\text { Швеції }\end{array}$ & м. Стокгольм & $\begin{array}{c}\text { Відкрився } \\
20 \text { квітня } \\
2015 \text { р. у } \\
\text { Стокгольмі. }\end{array}$ & $\begin{array}{l}\text { Кіномани зі Швеції та інших } \\
\text { скандинавських країн отримали } \\
\text { можливість побачити новітнє } \\
\text { українське кіно та підтримати } \\
\text { українців. }\end{array}$ \\
\hline 24. & $\begin{array}{l}\text { Міжнародний } \\
\text { студентський } \\
\text { кінофестиваль } \\
\text { "Пролог" }\end{array}$ & м. Київ & $\begin{array}{l}2000 \text { р.; } \\
18 \text { років }\end{array}$ & $\begin{array}{l}\text { У фестивалі брали участь } 16 \\
\text { вітчизняних та } 8 \text { зарубіжних } \\
\text { кіношкіл - } 3 \text { Білорусії, Болгарії, } \\
\text { Вірменії, Грузії, Росії, Франції } \\
\text { тощо. }\end{array}$ \\
\hline 25. & $\begin{array}{l}\text { Кінофестиваль } \\
\text { «Світло» }\end{array}$ & м. Київ & $\begin{array}{l}2013 \text { р.; } \\
7 \text { років }\end{array}$ & 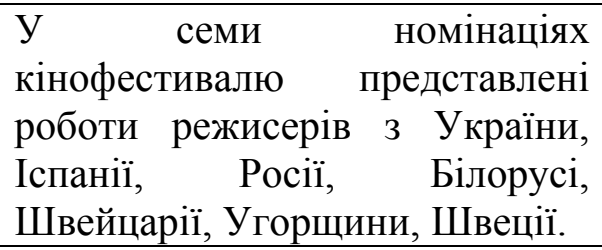 \\
\hline 26. & $\begin{array}{l}\text { Міжнародний } \\
\text { правозахисний } \\
\text { кінофестиваль } \\
\text { «Ступени» } \\
\text { (при підтримці } \\
\text { Міністерства } \\
\text { культури України та }\end{array}$ & м. Харків & $\begin{array}{l}2007 \text { p.; } \\
6 \text { років }\end{array}$ & $\begin{array}{l}\text { На першому міжнародному } \\
\text { кінофестивалі у } 2007 \text { р. було } \\
\text { продемонстровано } 70 \text { робіт з } 20 \\
\text { країн світу; на другому - понад } \\
100 \text { робіт з більше як } 30 \text { країн } \\
\text { світу; на третьому - було } \\
\text { показано } 179 \text { кращих робіт } 343\end{array}$ \\
\hline
\end{tabular}




\begin{tabular}{|c|c|c|c|c|}
\hline & $\begin{array}{l}\text { представництва } \mathrm{OOH} \\
\text { в Україні) }\end{array}$ & & & $\begin{array}{l}\text { країн світу. } \\
\text { Всього на кінофестивалі було } \\
\text { представлено більш ніж } 300 \\
\text { фільмів } 360 \text { країн світу. }\end{array}$ \\
\hline 27. & $\begin{array}{l}\text { Перший } \\
\text { Міжнародний } \\
\text { фестиваль } \\
\text { короткометражного } \\
\text { кіно «Харківський } \\
\text { бузок» }\end{array}$ & м. Харків & $\begin{array}{l}2009 \text { р.; } \\
14 \text { років }\end{array}$ & 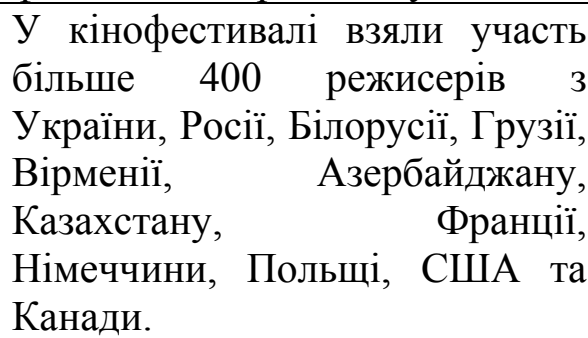 \\
\hline 28. & $\begin{array}{l}\text { Фестиваль мистецтва } \\
\text { кіно для дітей та } \\
\text { підлітків } \\
\text { «Чілдрен Кінофест» }\end{array}$ & $\begin{array}{c}\text { Більше } 20 \\
\text { міст України }\end{array}$ & $\begin{array}{l}2014 \text { р.; } \\
8 \text { років }\end{array}$ & $\begin{array}{l}\text { Представлені фільми з Швеції, } \\
\text { Норвегії, Данії, Франції, Італії, } \\
\text { Люксембургу, Ірландії, Великої } \\
\text { Британії, Естонії. } \\
\text { У } 2018-2019 \text { роках до участі у } \\
\text { конкурсі було подано понад } 150 \\
\text { заявок від дітей з усієї України, } \\
\text { У } 2019 \text { році фестиваль відбувся } \\
\text { у } 24 \text { містах, покази відвідали } \\
\text { близько } 50 \text { тисяч глядачів. }\end{array}$ \\
\hline
\end{tabular}

У результаті проведеного нами дослідження можна зробити висновок, що Україна активно залучається до проведення кінофестивалів у своїй державі, що свідчить про іiї відкритість і одночасно, презентацію на міжнародній арені. I хоча тематика кінофестивалів $є$ досить різноманітна, i кількість учасників, які беруть участь у цих заходах, щороку збільшується, проте, є певні моменти, на яких варто сфокусувати увагу:

1) на офіційному сайті Міністерства культури не було жодної інформації щодо проведення кінофестивалей, і бажаючи взяти у них участь повинні вишукувати анонси про той чи інший фестиваль 3 інших сайтів, які іноді є вже закритими;

2) інформація, яка представлена на інших сайтах, часто є застарілою та не актуальною, або взагалі відсутня.

Все це свідчить про неефективність державної політики у сфері культури, зокрема, в організаційній політиці кінофестивалів.

3) загальна кількість країн-учасниць, які брали участь у різних кінофестивалях в України за час їх проведення, коливається від восьми до 4000, проте, слід зазначити, що здебільшого вони були представлені країнами 
з СНД та країнами Свропи, активним учасником також є Норвегія. Такі країни, як США, Великобританія, Канада, меншою мірою були залучені до цих творчих заходів.

Висновки і перспективи подальших досліджень. Таким чином, можна зробити висновок, що участь тієї чи іншої країни світу у кінофестивалях, що організовуються в Україні, $€$ відображенням тієї політики, що проводиться в середині кожної із держав. I завдання України $€$ вибудувати свої відносини з країнами таким чином, щоб про нашу державу дізнавались не лише вихідці з СНД та представники європейських держав, а країни Східної Азії, Австралії, Африканського континенту та інші. А інструментом цієї державної політики виступають кінофестивалі як важлива складова культурної дипломатії України. У цифрову епоху уперше виникає глобальний простір комунікації. Воно радикально змінює політичну вартість культурних фактів, дозволяючи державам домагатися своїх цілей, застосовуючи інструменти «м'якої сили» щодо вирішення військового та економічного питання.

\section{ЛIТЕРАТУРА}

1. Берест, Б., 1962. Історія украӥнського кіна. [online] Нью-Йорк. Доступно: http://diasporiana.org.ua/ukrainica/berest-bistoriya-ukrayinskogo-kina/ [Дата звернення 25 Листопад 2019].

2. Детектор Медіа, 2015. У столииі Швеиії відбудеться Перший північний фестиваль украӥнського кіно. [online] (Останне оновлення 17 Квітень 2015) Доступно: detector.media/infospace/article/106182/201504-17-u-stolitsi-shvetsii-vidbudetsya-pershiipivnichnii-festival-ukrainskogo-kino/ [Дата звернення 23 Листопад 2019].

3. Кара-Мурза, С. Г., 2003. Манипулячия сознанием. [online] Доступно: http://www.lib.ru/POLITOLOG/karamurza.txt [Дата обращения 24 Ноябрь 2019].

4. Кіно Україна, 2019. «Кінофестивалі - Кіно в Україні». [online] Доступно: https://kinoukraine.com $>$ spysok-

kinofestyvaliv-v-ukra [Дата звернення 23 Листопад 2019].

5. Кіссинджер, Г., 2018. Дипломатія.

\section{REFERENCES}

1. Berest, B., 1962. Istoriia ukrainskoho kina. [online] Niu-York. Dostupno: http://diasporiana.org.ua/ukrainica/berest-bistoriya-ukrayinskogo-kina/ [Data zvernennia 25 Lystopad 2019].

2. Detektor Media, 2015. U stolytsi Shvetsii vidbudetsia Pershyi pivnichnyi festyval ukrainskoho kino. [online] (Ostannie onovlennia 17 Kviten 2015) Dostupno: detector.media/infospace/article/106182/2015 -04-17-u-stolitsi-shvetsii-vidbudetsya-pershiipivnichnii-festival-ukrainskogo-kino/ [Data zvernennia 23 Lystopad 2019].

3. Kara-Murza, S. G., 2003. Manipulyaciya soznaniem. [online] Dostupno: http://www.lib.ru/POLITOLOG/karamurza.tx $\mathrm{t}$ [Data obrasheniya 24 Noyabr 2019].

4. Kino Ukraina, 2019. «Kinofestyvali - Kino v Ukraini». [online] Dostupno: https://kinoukraine.com»spysok-

kinofestyvaliv-v-ukra [Data zvernennia 23 Lystopad 2019].

5. Kissyndzher, H., 2018. Dyplomatiia. 
Переклад 3 англійської М. Гоцацюка, В. Горбатька. Київ: Вид. група КМ-БУКС.

6. Укрінформ Мультимедійна платформа іномовлення України, 2019. Третій Міжнародний дитячий кінофестиваль Kids Movie Fest. [online] Доступно: https://www.ukrinform.ua/rubricculture/2460888-kids-movie-fest-vidkrieplaneta-tisi-stvorena-za-ucasti-ditej-bezsluhu.html [Дата звернення 22 Листопад 2019].

7. Шиллер, Г., 1980. Манипуляторы сознанием. Перевод с английского Я. Н. Засурский. Москва: Мысль.

8. DOCU DAYS UA, 2019. XVI Міжнародний фестиваль документального кіно про права людини Docudays UA. [online] Доступно: https://docudays.ua/history/ [Дата звернення 24 Листопад 2019].

9. FESTAGENT, 2019. «Каталог кинофестивалей со всего мира». [online] Доступно: https://Festagent https://festagent.com>festivals [Дата звернення 23 Листопад 2019].

10. KYIV INTERNATIONAL ADVERTISING FESTIVAL, 2018. Київський Міжнародний Фестиваль Реклами 2018/2019. [online] Доступно: https:// kiaf.com.ua/news [Дата звернення 23 Листопад 2019].

11. KYIV INTERNATIONAL SHORT FILM FESTIVAL, 2019. LESS IS MORE. [online] Доступно: https://kisff.org [Дата звернення 23 Листопад 2019].

12. Lenczowski, J., 2008. «Cultural Diplomacy, Political Influence, and Integrated Strategy». In: J. Michael Waller, ed. Strategic Influence: Public Diplomacy, Counterpropaganda, and Political Warfare. Edited by. World Politics Press, USA. 2008. pp.74-100.
Pereklad z anhliiskoi M. Hotsatsiuka, V. Horbatka. Kyiv: Vyd. hrupa KM-BUKS.

6. Ukrinform Multymediina platforma inomovlennia Ukrainy, 2019. Tretii Mizhnarodnyi dytiachyi kinofestyval Kids Movie Fest. [online] Dostupno: https://www.ukrinform.ua/rubricculture/2460888-kids-movie-fest-vidkrieplaneta-tisi-stvorena-za-ucasti-ditej-bezsluhu.html [Data zvernennia 22 Lystopad 2019].

7. Shiller, G., 1980. Manipulyatory soznaniem. Perevod s anglijskogo Ya. N. Zasurskij. Moskva: Mysl.

8. DOCU DAYS UA, 2019. XVI Mizhnarodnyi festyval dokumentalnoho kino pro prava liudyny Docudays UA. [online] Dostupno: https://docudays.ua/history/ [Data zvernennia 24 Lystopad 2019].

9. FESTAGENT, 2019. «Katalog kinofestivalej so vsego mira». [online] Dostupno: https://Festagent

https://festagent.com >festivals [Data zvernennya 23 Listopad 2019].

10. KYIV INTERNATIONAL ADVERTISING FESTIVAL, 2018. Kyivskyi Mizhnarodnyi Festyval Reklamy 2018/2019. [online] Dostupno:https:// kiaf.com.ua/news [Data zvernennia 23 Lystopad 2019].

11. KYIV INTERNATIONAL ADVERTISING FESTIVAL, 2018. Kiyivskij Mizhnarodnij Festival Reklami 2018/2019. URL: https:// kiaf.com.ua/news [Data zvernennya 23 Listopad 2019].

12. Lenczowski, J., 2008. «Cultural Diplomacy, Political Influence, and Integrated Strategy». In: J. Michael Waller, ed. Strategic Influence: Public Diplomacy, Counterpropaganda, and Political Warfare. Edited by. World Politics Press, USA. 2008. pp.74-100.

\section{Інформація про авторів}

Комар Руслана Олександрівна - старший викладач кафедри «Фінанси та банківська справа» Національного аерокосмічного університету ім. М.Е. Жуковського «XAI»; e-mail: r.komar@khai.edu ORCID ID: https://orcid.org/0000-0003-0360-884X

Солових Свгенія Миколаївна - кандидат політичних наук, доцент кафедри міжнародних відносин, міжнародної інформації та безпеки, Харківський національний університет імені B.H. Каразіна; e-mail: j.m.solovikh@karazin.ua ORCID ID: https://orcid.org/0000-0002-08402835

Стаття надійшла до редакції: 28.11.2019 р. $\quad$ Прийнята до друку: 14.12.2019 p. 